\title{
A Review of the Satire and Remonstrant Satire-Processing in the Poems by Sayed Hasan Hosseini with an Emphasis on the Collections "Safar Nameh Gerdbad, Boradeha and Noushdaruy-e-Tarhe-Generic"
}

Una revisión de la sátira y el procesamiento demostrativo de la sátira en los poemas por Sayed Hasan Hosseini con énfasis en las colecciones "Safar Nameh Gerdbad, Boradeha y Noushdaruy-eTarhe-Generic"

Hossein Salimi

Assistant Profeser, Persian Gulf University, Boshehr, Iran.

ORCID: https://orcid.org/0000-0002-2117-5905

* Correspondence

Email:hsalimi@pgu.ac.ir
Cite as :

Salimi H. A. (2021). Review of the Satire and Remonstrant Satire-Processing in the Poems by Sayed Hasan Hosseini with an Emphasis on the Collections "Safar Nameh Gerdbad, Boradeha and Noushdaruy-e-Tarhe-Generic". Propósitos y Representaciones, 9 (SPE1), e883. Doi: http://dx.doi.org/10.20511/pyr2021.v9nSPE1.883 
A Review of the Satire and Remonstrant Satire-Processing in the Poems by Sayed Hasan Hosseini with an Emphasis on the Collections "Safar Nameh Gerdbad, Boradeha and Noushdaruy-e-Tarhe-Generic"

\section{Summary}

Sayed Hasan Hosseini is amongst the successful and innovative contemporary poets; his poetical themes and subjects predominantly serve the expression and delineation of the people and the community's pains and problems. Due to the same reason, he chooses satire for expressing his social thoughts in various periods of his practicing of poetry and it is by doing so that he not only criticizes and corrects the social abnormalities but he also invites the society and the people to ponder and think. In the poems by Sayed Hasan Hosseini, poetry is not only seen in the single elements and words but also in the level of sentences and themes, as well. Social evolutions and the people's lack of adherence to the revolutionary and Islamic values can be enumerated amongst the most important reasons of satire's presence in Hosseini's poems. The poet's imagination and meticulousness subject to the effect of Indian style has also caused the entering of a caustic and serious satire in his poems making them have eloquence and artistic value as well as a sort of audience-adorned sincerity. The subjects of his satires substantially contain social criticism occasionally interlaced in some of the cases with the historical and religious incidents. The present article uses a descriptive-analytical method to investigate the satire-creation methods and satirical subjects in the poems b Sayed Hasan Hosseini with an emphasis on three poetical collections by him, namely "Safarnameye Gerdbad", "Boradeha", and "Noushdaruy-e-Tarhe-Generic".

Keywords: satire, caustic poetry, Sayed Hasan Hosseini.

\section{Resumen}

Sayed Hasan Hosseini se encuentra entre los poetas contemporáneos exitosos e innovadores; Sus temas y temas poéticos sirven principalmente para la expresión y delineación de las personas y los dolores y problemas de la comunidad. Debido a la misma razón, elige la sátira para expresar sus pensamientos sociales en varios períodos de su práctica de la poesía y es así que no solo critica y corrige las anomalías sociales, sino que también invita a la sociedad y a las personas a reflexionar y pensar. En los poemas de Sayed Hasan Hosseini, la poesía no solo se ve en los elementos y palabras individuales, sino también en el nivel de las oraciones y los temas. Las evoluciones sociales y la falta de adhesión de la gente a los valores revolucionarios e islámicos se pueden enumerar entre las razones más importantes de la presencia de la sátira en los poemas de Hosseini. La imaginación y la meticulosidad del poeta sujetas al efecto del estilo indio también han provocado la entrada de una sátira cáustica y seria en sus poemas, haciéndolos tener elocuencia y valor artístico, así como una especie de sinceridad adornada por el público. Los temas de sus sátiras contienen sustancialmente críticas sociales ocasionalmente entrelazadas en algunos de los casos con incidentes históricos y religiosos. El presente artículo utiliza un método descriptivo-analítico para investigar los métodos de creación de sátiras y temas satíricos en los poemas b Sayed Hasan Hosseini con énfasis en tres colecciones poéticas suyas, a saber, "Safarnameye Gerdbad", "Boradeha" y "Noushdaruy- e-Tarhe-Genérico ".

Palabras clave: sátira, poesía cáustica, Sayed Hasan Hosseini.

\section{Introduction}

\section{Satire Defined}

"Literally, Tanz [Satire] is an Arabic word meaning ridiculing and mocking" (Dād, 2004), and (Horri, 2008). But, in literary terms and in recent years, it has been more an equivalent for the English word 'satire' (Pollard, 1999). "In literary terms, satire is the use of a series of words for indirectly and in a ridiculing tone of voice criticizing the filths, corruptions and immoralities 
of a person, a group of people, a community or a given nation and, though it makes the listener laugh, it aims at correcting and purifying". As interpreted by Abrams, "laughter is the satire's weapon for correcting the depravities and shortfalls" (Hosseini, 2008).

\section{Goals of Satire}

Satire is manifested in the works by a poet or an author when there are themes of responsibility and commitment existent in his thoughts because the real and true satire cannot be always actualized away from critical attitudes towards the affairs and things in our periphery. Essentially, satire is per se a manifestation of commitment and responsibility. In today's committed and semantic-oriented literature as compared to that of the past, satire has become more ethical and more human and it accordingly tries to stay away from the borders of burlesque, facetious sayings and comics and not to get mixed with them. Nowadays and in the today's committed literature, the satire and satire-processor's area of involvement incorporates the intellectual, ideological, religious, political, social, ethical and economic matters.

\section{Techniques and Methods of Satire-Processing}

It can be discerned in a more precise glance at the satirical works that there are applied special techniques in them. The researchers who have performed works in this regard tend to differently categorize these techniques. Dr. Ali Asghar Halabi has presented these methods as follow in the third section of the book "an introduction to satire and jocundity in Iran": humiliation and, in some of the cases, stripping, comparison with animals, assimilation of objects and words (parody falls in this category), stupefying, blemishing the symbols, exaggerated and insensible extolment, derision, curse and insult (Boradeha in this category).

\section{Satire in the Poems on Islamic Revolution and Holy Defense}

The decades before and after the Islamic Revolution have been accompanied with a lot of rises and falls that have also entangled the Revolution especially because our revolution has been followed by other global revolutions that have been accompanied with wars but our revolution has had results and accomplishments a lot greater than any other revolution. Under such circumstances, spirits undergo metamorphosis and every agreeing or disagreeing human being is subjected to the effect of events or incidents inherent in such critical situations. Becoming a poet or a writer is also laid on the foundation of these same sensitivities and criticalities. In the most sensitive and most critical period of history, this territory has been proud of such elders as Naser Khosrow, Sana'ei, Ferdowsi, Mowlavi, Sa'adi, Hafiz and others and boasted its magnificence before the eyes of the time's auspicious and inauspicious situations (Gholami, 2010).

\section{Statement of the Problem}

Jonathan Swift (1667-1745) is an English satirist and writer who realizes satire "as a mirror wherein the observers generally discover the face of nobody but their own selves and this is the substantial reason for the great welcoming of satire worldwide and this is also why not so many individuals feel teased by it" (Hosseini, 2008). "In Iran's classic literature, satire is typically an independent and correctional artwork that is rarely seen without a critical and social approach and it has been always developed in the form of streaks of discourse and narrations. The greatest satirist who used satire in Persian literature as a means of attacking the norms, habits and certain social classes' depravities was Obaid Zakani. During the late Qajar Era (1779-1926), the fights by the constitutionalists drew the poets and writers' attentions towards the social and political matters and instigated political and social critical thinking in them following which satire was envisioned as an effective tool for illuminating the minds of the community's deprived classes; it was due to the same reason that this period of time can be viewed as the blossoming era of satire in Persian literature" (Hesampour et al, 2011). It was since this period of time that satire comes to existence with a political, social and critical approach in the works by the poets and authors. Amongst the huge number of the satirists from 
this period of time, individuals like Ali Akbar Dehkhoda, Nasim-e-Shomal, Iraj Mirza, Mirzadeh Eshghi, Abu Al-Qasem Lahuti and Abu Al-Qasem Halat can be mentioned. Their satires are very much close to the standards of a perfect satire.

\section{Study Background}

Studies performed in the area of satire can be divided into two general sets: a) studies performed regarding the techniques of composing satire and its nature and kinds; b) studies that have searched for satirical techniques in certain works.

As for the investigation of the contemporary poets' works from the perspective of satire, the article named "investigation of satirical themes in the poems by Qaisar Aminpour" can be pointed out.

\section{Text}

\section{Satire in the Poems by Sayed Hasan Hosseini}

All the poems composed by Sayed Hasan Hosseini have tints of satire. In fact, he is unexampled in the area of satire amongst the poets who compose about Islamic Revolution and Holy Defense. In his most serious, most religious and most revolutionary poems, as well, he uses satire and that a kind of fine and perfect satire. It is a sort of satire that is serious meanwhile being a joke and he always presents his jokes within the format of serious words. In his poetry, satire has been very artistically reflected. Conflict and paradox are always existent in his satires and the readers can readily see them. It can be stated that his poems are laid on the premise satire. Although the magnificence of satire is not identical in all parts of his poems, his satires are fluid and natural. Myths and mythical figures play accentuated roles in his poems and culture and true belief have been vividly and transparently manifested in them. In his satires, Hosseini takes advantage of paradox for showcasing the conflicts and oppositions. Personification and its various kinds are abundantly recognizable in his satires. His satires feature social and political themes and the true justice is intermixed in them with tonalities of dynamic culture and, due to the same reason, his poems are far away from joke and burlesque and very much close to real satires. The structure of his satires is new and unprecedented. Words are presented in a fluid and coherent texture and narrate the poet's internal feelings and psyche. His literary logic that has been offered without any sort of artificiality and formality is a mixture of satire and burlesque and that in such a way that it is difficult to distinguish satire from burlesque therein and this is well-indicative of the poet's creativity and innovation and versatility:

"O' the ancient prison of the universe! O' the Rotating Wheel! I will punch your wall with a fist! A Fist!"

"O' the old silence! O' the tyrant! Your turmoil finally killed us"

"No poet even spoke of the heart's complexities; we were killed by this coarse riddle"

"The poets with upright back are destitute; solace to the hunch-back poets" (Hosseini, 2008).

In fact, satire serves the arrival at a rank of perfection and glory in language and it can look at all the attachments, belongings and, in a single phrase, the time's common struggles and endeavors from a higher standpoint. The poems by Sayed Hasan Hosseini approach his peripheral issues from this same loftiest apex of satire and drag the audience to a laughter accompanied by hesitation and meaningful contemplation. He calls the new century "the century of two thousand plus one" and refers to it by using such expressions as "the century of the real sorrows" and "virtual happiness means". It is this same conflict between the real griefs and virtual happiness that encourages this time's thinker poet to compose satire. Although such a type of satire serves the expressing of the ridiculousness of the world's incidents and barriers, its grief and sadness is more accentuated than laughter and joke:

"The century of the wastage storm; the century of darkness rain" 
"Cries from the bottom of the heart; the wrong laughter"

"The century of the real sadness; virtual happiness"

"Every instant in promotion; the industry of coffin-making"

"Satire and other types of jocundity and joking have always been concomitantly accompanied with laughter and happiness and cheer. However, laughing sometimes as bitter and as dreadful as the realities is a prelude to the reviewing and thinking more subtly about the world's incidents. It is also worth mentioning that there is a deep relationship between painful satire and religious thinking. Kierkegaard (1814-1855), the founder of existentialism, has the following words in this regard: "satire is the last stage of existential pondering before reaching faith; satire and burlesque differ from one another in that satire, unlike burlesque, is empty of sympathy. The person who looks at the earthly mankind's tasks and affairs and ant-like struggles through the lenses of deliverance and abstinence would find every normal thing strange and ridiculous; he would see daydreamers who are unaware of the God and their own selves and wander about everywhere; such individuals would see more ridiculous aspects even if they adopt a loftier approach. The highest and the most sublime of such viewpoints is the religious approach. The religious human being can laugh more than anybody else at the mankind and the world's masterpieces" (Halabi, 1995).

Hasan Hosseini is a heedful poet and a thoughtful artist who uses this same religious approach to the today's life which is empty of ethics and humanity and mocks its manifestations in a satirical language. Although satire and joking and scrupulousness are seen in all his works, his poetical collections "Noushdaruy-e-Tarhe-Generic", "Safarnameye Gerdbad", "sparrow and Gabriel" and "in the heavens of silence" should be considered as works wherein satirical art is more manifested:

"The rare appearance of laughter on lips; the strangeness of flower in the deserts"

"The gifts, the death of Maryam; the presents, the grave injuries"

"The century of loneliness and bitterness; the season of indigence and failure"

"Mass graves, individual houses" (Hosseini, 2008).

This horrible image of the opposition between mass graves and individual houses signals the special meticulousness of Sayed Hasan Hosseini.

"The index of the confusion has gone to the peak of the sky"

"In the spinal cord of the kindness, there is a shrapnel piece of inhumanity"

"The century of the prohibitions' promotion; offering of massive faith"

"Compulsory disloyalties; abominable kindnesses"

In every single one of these words and verses, a sort of fillip and derision of the new world's specificities and subjects can be seen. It is the world that when looked at though contemplation and hesitation, it will be seen that nobody's inside and psyche is calm even with all its economic and industrial facilities and progresses. The confusions are increasing on a daily basis and the kindnesses are fading away from amongst the human beings. Love and affectionate feelings and likings are valueless in the market of the today's world and the people think of nothing but trade and money:

"The century of the corrupt opportunities, the inappropriate moments"

"The century of the love's resignation, the century of the shopkeepers' domination"

Hatred and enmities are increasing day in day out and no sooner are smiles inscribed on the lips that they vanish in the faces:

"There is an image of an idle smile on the lips of lenience"

"Kindnesses are brief and hatreds are detailed"

In many of the cases, Hosseini ironically uses the Islamic ĀYĀT and hadiths for expressing his intentions. In the following poem, he uses the pictorial capacity of an allegory in the well-known statement "imagery is the residence place of the truth" and portrays the satirical position of the today's human beings in the roaming between the truth and the imagery:

"They say there is a bridge from imagery to the truth; alas, my love's lifetime was spent on the bridge" 
In poetry, as well, he uses this same method in addition to conflict and paradox to criticize his contemporary people's situation and status and forgetting of the sublime accomplishments and values of revolution and martyrs:

"What have we done in this world except ignorance? What have we found instead of what we have lost?"

"O' God! O' God! What have we done except befriending others in lieu of you?"

"We have been entrusted with a gift but we have forgotten it; what have we done?"

"In this lack of opportunity, O' my heart, tell me what else have we done except idling"

"Do not ask me any question for it is useless for I do not know what we have done with the syllogism"

"We had an archaeological serenity; tell me with what we have exchanged it?"

"All the components of the universe are busing doing a thing or other; tell me what we have done in this world with such a meaning"

"The book of love was entirely readable; tell me what we have done with the preface"

"What have we brought other than explanation of the problem? What have we done other than proposing the riddles?"

"The martyrs did what they had to but we do not know what we have done"

In the following satirical and critical sonnet, as well, the expression "resistance against the winds" refers to the statement by His Highness Imam Ali (PBUH) who compares the human beings with loose elements to the flies that are driven this or that way with every wind. The emphasis on not bowing to the winds of deceit and hypocrisy is completed immediately by a reference to the time's deceitful smile; then, the poet speaks of his own immunity against the spiritual deceits and makes a reproaching reference to his own devilish zeal for the denial of the sanctimonies:

"I am the meaning that is being destroyed; I am under the house custody of the words"

"I do not prostrate to the winds; I have a high luck in my forehead"

"Tell the time's stone face to deceive me by its cement-like smile"

"It is not easy for me from now on to leave my heart behind for I am the architect of the bridges of destruction"

"Stop frequently hitting the individuals by the stick of the God otherwise my devilish zeal will be increased"

"Your pride broke my stem; you should be afraid of my pollination"

Such a type of look at the spiritual concepts and enjoyment of the satirical expressions for showing the distance from honesty and faith to hypocrisy and sanctimony is followed by a valuable and promising result considering Sayed Hasan Hosseini's deep familiarity with Islamic culture and his brilliant history of Persian poetry.

By occasionally referring to the contemporary people's faithlessness and lack of belief, Hosseini criticizes the impure and deceptive petitions and prayers:

"If the entreaties to the God boil from inside the pained heart, the head of the granting wave will be beneath the water"

He sometimes explicitly and bitterly and stingily reprimands those who are taking advantage of religion as a means of their own business and trade and complains about the people's turning of their faces away from religion and faith:

"The claim for religiosity is nothing more than a shop; the body of the right has its half of the vigor left"

"The discussion on freedom in this Jewish concoction is nothing more in the heart other than the bone's injury"

"These struggles are nothing more than a shock until the child of freedom sleeps"

"In the battle against love, the borrowed intellect is nothing more than an inept hero"

"The back of the religion was curved in the combat against the world; our Rostam was left with nothing more than a bow"

"The fake ink of the certitude and sureness is the eyeliner of nothing more than a suspicion" 
In the poems by Sayed Hasan Hosseini, implications drawn on the religious culture are the causes deepening the meaning and making the satirical connotations interpretable:

"My eyes did not seen anything from the world's lock of hair other than distress; they did not see anything except distress from this dark lock of hair"

"Atop of the Niles of helplessness, my Moses did not see any passage other than the bridges of destruction"

"My joseph did not see anything other than pure faithlessness and utmost hypocrisy from these religious brothers!"

Or,

"I am the injured Jesus of the first morning and my friends are awaiting my last supper"

Or,

"We spread the ethereal garment of the love that is the truth of the religion under the footsteps of the imagery"

In the following sonnets, as well, the same functions are also seen:

"My heart intended to climb up to the top of Alvand Apex, i.e. going up from the soil to give a kiss on the God's feet"

"The world's mercy and comfort is the product of illiteracy; both of the worlds curse and damn the sages"

"The cause of a full laughter is a flowing tear like the Christ of our heart that has been deceived by a smile"

"If being adorned by a person lies in hating Imam Ali (PBUH), I spit on such an adornment and such an attachment"

"O' wayfarers, may your palate be sweet and your way be demure for you have travelled the distance from the flattery's Bokhara to Samarqand"

Also,

"I made up my mind to travel on sea but never on foam/I decided to find gem but never seashell"

"I previously spoke to Jesus about my pain but I never endowed my future donkey!"

"My offended ears did not hear anything other than the command of "do not fear"" dishonored"

"However, I whispered it in my heart's ears that you should remain impartial but never

The effective, influential and stinging expressions in Sayed Hasan Hosseini's satires assault the false claimants or, in other words, the straw champions and the actors of the false and preposterous epics in many of his compositions and, of course, he does not see himself immune of the criticism and scorns out of his magnanimity and humbleness:

"We have made myths to your name; we have made houses in the fables"

"It is a wonder that we heard the night's commotion in the morning but we did not recognize it"

"The same blades that we were pulling out cut off the throat of our outcry"

"Read! It is the story of the mill and the wind and the story of us, the spear-holders who were raiding" lost!"

"The destined gambling reached its termination but they did not say whether we won or

"The tongue-tied ewe that we were pampering has become a wolf; it baptized in its flowing blood and we prayed over its head"

"Our night-wakefulness disposition was the chastity of this farm; we fell asleep and we submitted it to the boar"

"We were trapped in a cage out of the crave for freedom; our trap was the wing and feather we opened"

He also sometimes sarcastically complains about the narrow-minded and jealous rivals and friends:

"Since they cannot stand watching a rival and competitor; they always want to see scoundrels" 
"In the history's mid-winter alleys, they want your heart to be wandering like a bat"

"Do not speak about the pain and the nobility zeal for rivals wish to see you indecent and painless"

"Nightmare is the wonder seen by those who have gone astray about the unfinished path and contest"

"I hope that they will one day see some men upon looking at the mirror!"

And, in the last verse of the sonnet, the poet's indirect expression decreases the bitterness of the speech a little but simultaneously doubles the influential effect of the satire existent therein.

In the sonnet, the "smell of thorn" which has been used in all of the verses introduces a complaint accompanied by sarcasm and satire:

"I am worried about both your look and also about the time-to-time visiting of you"

"What should I do? I smell thorn from your flower and greeneries and plants"

"My frank ear does not conform to your striped tumult"

"My bitter whimper does not match with your burst of laughter"

"I am a secluded and grieved song outside the zeal of your musical system"

"My secret was turned into ashes in the fire and the wind blew in your hats"

"The bucket was filled with the blood of Joseph; your well was the lair of the wolf"

In the beautiful and satirical sonnet of "abundance", a description has been presented about the invertedness of the "time's work" accompanied in some of the verses with a surprising and ponderable satire:

"One can barely breathe for the large number of mutinies coming one after the other"

"The deployment of the army of romance has been assigned to the commanders of lust"

"And, the peak flight of the eagle is inherited by the zapped cry of the housefly"

"The outcry of the tired lovers, as well, is answered by the sheriff instead of the just ruler"

"The lips are scarcely provided with the breath even though there are several lines of flowers and breeze"

"It is abundance and affluence; every bird can have several cages"

In the couplet poems' collection, named "waters and swamps", as well, the time's unevenness has been inversely discussed in great details and almost all the verses of these couplet poems are accompanied by a stinging and annoying satire. Several verses of these couplet poems are represented here though the satire existent in them was pointed out also in the previous lines:

"The fact of the matter is that the quantity was gradually increased and the goods' supply took the place of our values"

"The roof of piety was dampened under the rains of ignorance; the hard roofs became wet like cardboards"

"What magic could drive away love from the hearts and turn inferiority to art and magnanimity to flaw?"

"A love robbed the house of our hearts and went away and the electrical circuit abruptly underwent shortening that was followed by outage"

"The chests were entirely colored by darkness; the face of the mirror was rusted with forgetfulness"

"The gardens of the chests became empty of the cedars; the loves started serving money and became frail"

"The body of the godly love was turned into a spindle out of leanness; the head of the transcendental feelings became hollow"

"The hearts gradually started getting accustomed to the luxury of the gold; they rotted in the wish for silver and gold and started giving off stink"

"The tribe that worships the gold from the bottom of the heart is usually found heading the group of the indigents"

"The gold-worshiping care-taker and the caring gold-worshipper are the ones making this convoy lag behind till the morning of the Judgment Day" 
"An ominous sun enlivened the souls and made the dried dragon motile once again"

"The mutinying Coptics have resided the elevated grounds; the magicians have colluded with the Samaritans"

"I have seen the downfall of the greenhouse, the needled wings of the butterflies"

"Let me know the mutiny that sealed the shop of loyalty and coagulated the blood of serenity in the veins of faith"

"Tell me what has happened to the lucidness of the mirrors? What destroyed the transparent ego of the mirrors?"

Sayed Hasan Hosseini presents such epical and influential expressions and such belligerent and occasionally aggressive satire in his poems and he also makes use of stinging and sarcastic satires in the face of the indifferent poems and irresponsible and inactive poets: friends!"

"In the name of God, O' friends, I am tired! I swear by your lives that I am tired O'

"From the foot to the head or vice versa or, in other words, I am tired O' friends"

"Tumult, commotion, uproar and silence, voiced and unvoiced, I am tired O' friends!"

"I am tired of the warning sounds of the ancient times; of the notifying and cautioning sounds O' friends!" friends"

"And, I am also tired of the sonnets wearing eyelash makeup; of the "Ava" poem O'

"I am tired of knowledgeability pretense in the new style so I am thus tired O' friends"

The collection "Noushdaruy-e-Tarhe-Generic" as well as the collection "Boradeha" are amongst the most artistic and most beautiful compositions in the area of the contemporary literary satires showcasing Sayed Hasan Hosseini's protesting and critical perspectives regarding the social, political, economic and cultural issues of this time. Sayed Hasan Hosseini criticizes and ridicules the romantic and superficial pains and the artificial and fabricated anguishes and griefs and, in one word, the lustful romantic literature in the following poem through the use of a satirical language:

"About her sadness and in a perfect sense/a poet composed a poem/smoke started rising up from the paper plate" (Hosseini, 2008).

The satirist poet can be called "meaning caricaturist" because he seminally chooses his intended setting and subsequently magnifies or downsizes aspects of the purport in respect to the goal he has in such a way that the issue is peculiarly, strangely and jokingly perceived by the readers. Therefore, satirists, like caricaturists, try magnifying the flaws and defections and paradoxes and differences so as to be able to direct the audience's attention towards them with the explanation being that the ultimate and final goal of both magnification and downsizing of the flaws should be correction and reconstruction. When Hosseini writes "a poet did a magical work/the attendants all went to the resurrection desert"

In both these two short hemstitches, a group of poets is introduced that instigate uproar by their weird and imbalanced movements and present the ears of the audience more idle than they themselves with feckless and absurd compositions in great zeal and fervor: "A poet entered the college/at the gate/he gave his taste to the guard"

Criticism of the hypocrites and pretenders has caused operationalization of the tongue and expression faculty of the poets and writers who somehow felt commitment to art so as to engage in criticizing the behaviors and ethical properties of this group (Movahhed, 2003).

Sayed Hasan Hosseini portrays the immorality, misbehavior and inferiority of such individuals most beautifully in a small tableau of the following poem and engages in criticizing such an attitude in the society and presents his readers with a jocund, joking, innovative and, in the meanwhile, expressive and impressive image of his poems. In this poem, he presents such a phrase as "the toilet well" to mean the world's blood of heart. It seems that such a satirical expression indicates that the final result of such persons' enjoyment of the corporeal belongings is nothing more than these filths and grimes: "a ring fell into the mouth of the toilet's well/a tradesman/to the elbow/put his hand into the world's blood of the heart" 
In the committed and idealist poetry, criticism of the material attitudes is amongst the cliché subjects. From the perspective of a committed person who takes superior criteria as the principles of his life, the reference to the mere corporeal scales for valuing the affairs is shortsightedness. The owners of some jobs and occupations like tradesmen and merchants are more exposed to the risk of materialism due to the expediencies of their jobs and they have been subjected to criticism in our literature due to their possession of these same attributes since long ago (Critchley, 2005).

In the following poem, the poet portrays a small scene of the behaviors and manners of a merchant like a filmmaker who records a short film lasting several seconds. Emphasizing on a special point of this scene, he tries unveiling his thought and showcase his materialistic mindset in the mirror of satire. It is here that the merchant wants to set a price for the petals of the red rose. Due to only thinking about the economic-material and monetary issues, he does not discern the rate and price of the red rose's petals. He cannot accept that a thing like a flower possesses spiritual, aesthetical and taste-based and emotional not material value: "a merchant said: Ah!/and, then, he went to the garden/set a price for the petal of a flower".

Of course, the terms like "Ah" and "setting a price" also point to more heinous meanings and concepts that need not to be mentioned herein. These are the meanings and concepts concealing the insolence to the personality of the merchant and his materialistic thoughts.

Social satires by Sayed Hasan Hosseini sometimes deal with the cultural aspect of things and criticize the society's cultural abnormalities. Such criticisms can be more observed in the collection "Boradeha". In the contemporary periods, the biggest cultural challenge of the third world countries and, especially, our country is fascination by the west and selling of the soul to the western culture. Due to the confrontation with the west's diverse and deceitful manifestations and appearances as well as detachment from the traditional and religious past, some have come to this negative belief that they have nothing and everything should be borrowed from the west and the western countries.

"This mindset was stabilized when some persons that were called enlightened minds started advertising in such a way that a given enlightened mind believed that we should become western-like entirely from head to toe so as to achieve progress and reach the civilization gates. Contrary to this group, there were also real and original enlightened minds who were making efforts to advertise self-esteem thoughts and return to one's own self and cultural originality and criticized the metamorphosis and transformation and thinking differently.

"The scholastic committed poets were a branch of this same group of enlightened minds. In criticizing the stream of cultural transformation, they occasionally seriously and sometimes through the use of satire utilized the instrument of poetry" (Sharifpour \& Ghaisari, 2012). Sayed Hasan Hosseini is amongst the most successful poets and writers who expresses his attitudes and beliefs regarding the cultural originality and return to one's own self in the collection "Boradeha" as well as his other works and applies the satirical format and accent and expression to criticize the alienated and west-fascinated enlightened minds. In a succinct phrase, he briefly and effectively summarizes his itinerary of his long journey to the civilized Europe in the following words: "the perfect text of the itinerary has been penned down in these lines/about the modern Europe: wonder, thought, hatred" (Hosseini, 2008).

Using a satirical expression, he addresses the west-fascinated enlightened minds and realizes them as being needful of the west and writes: "be the Damask rose so as not to be needful of the French perfume" (Salahi, 2003).

\section{Conclusion}

Sayed Hasan Hosseini should be realized amongst the most successful contemporary poets in the area of satire and social criticism for the fact that not so many poems by Sayed Hosseini can be found devoid of satire. If satire can be considered as the product of the human beings' attitudes and look at his peripheral situation and conditions, it becomes clear that Hosseini is fully aware of the social, political and ethical catastrophes and depravities existent in his society 
and tries to criticize these catastrophes and depravities so as to express his protest for the current conditions and simultaneously take steps towards correcting them. In other words, satire in Hosseini's poetry is mostly the result of the paradoxes and conflicts existent in the society. He is most predominantly worried about the destruction of the values he has personally witnessed and lived with. These are the values the description of which necessitates a magnificent and epical expression and the criticism of the individuals who have forgotten these values through the use of a stinging and sarcastic language. Due to the same reason, epical, stinging and impressive nature can be considered amongst the original characteristics of the caustic satires by Sayed Hasan Hosseini. On the other hand, as well, the language of Hosseini's satirical compositions is artistic and eloquent and replete with figurative speech and this has per se resulted in the satirical aspects of his poem. The central and pivotal theme and motif of Sayed Hasan Hosseini's composition is the social issues and subjects and paling of the revolutionary and Islamic values hence inclination towards modernity and industry-stricken world. $\mathrm{He}$ tries criticizing the social disorders and ignorance of the human and revolutionary values within the format of caustic and stinging and, of course, artistic satire and using magnificent and epical expressions to remind of the immoralities and society's unethicalness in the face of these disorders.

\section{References}

Dād S. (2004), "dictionary of literary terms", $1^{\text {st }}$ ed., Tehran: Morwarid Publication Institute, pp. 339-345.

Horri A. (2008), "the history of satire in Persian literature", $1^{\text {st }}$ ed., Tehran: Sureh Mehr Publication Institute, pp. 59-78.

Pollard A. (1999), "satire", tr. Saeed Soltanpour, $2^{\text {nd }}$ ed., Tehran: Markaz Publication Institute, pp. 78-99.

Hosseini H. (2008), "Boradeha”, Tehran: Sureh Mehr Publication Institute, pp. 66-92.

Gholami T. (2010), "satire in the poems on Islamic Revolution", journal of poetry, no.53, pp. 19-36.

Hosseini H. (2008), "Noushdaruy-e-Tarhe-Generic", $4^{\text {th }}$ ed., Tehran: Sureh Mehr, Center for the art area creations, pp. 47-56.

Hesampour S. \& Dehghanian J. \& Khavari S. (2011), "investigating the techniques of satire and joking in the works by Hushang Moradi Kermani", scientific-research journal of children and adolescents' studies, Shiraz University, spring and summer, 3(1): 128-136.

Hosseini H. (1990), "literary terms and expressions", v.1, Tehran: Niloofar Publication Institute, pp. 136-147.

Halabi A. (1995), "the history of satire and joking", Tehran: Behbahani, pp. 310-319.

Movahhed H. (2003), "satire and creativity", literary studies, summer and fall, pp. 70-84.

Critchley S. (2005), "about satire", tr. Sohail Somi, Tehran: Qoqnous Publication Institute, pp. 96-105.

Sharifpour E. \& Ghaisari R. (2012), "investigating the satirical themes in the memoires written on Holy Defense", journal of literature and resistance, pp. 201-213.

Salahi O. (2003), "laugher-makers and laughter-processors", $1^{\text {st }}$ ed., Tehran: Markaz Publication Institute, pp. 44-52. 